\title{
KÖRNYEZETI ZAJ A MINDENNAPOKBAN
}

\section{EVERYDAY ENVIRONMENTAL NOISE}

\author{
Bera József \\ Fonometro Környezettechnikai Bt., Magyarország, Siófok, Szép-Völgyi utca 59/16., \\ Telefon: +36-30-2544220, berajo@fonometro.hu
}

\begin{abstract}
The modern environmental problem visibly penetrated everyday life, nowadays it permeates the everyday activities and has become part of our lives in several aspects. Thus numerous environmental impacts have developed that we either need to live with, or we fight against these to a greater or lesser extent. Some people are not even aware of what to expect in the living environment, on the street, when travelling, at the workplace or even when clubbing. Noise shall deserve particular attention, most of the people immediately react upon it, and from perception point it possesses number one position. Current report provides information on the characteristics of everyday noise, on noise load levels, on disturbance related to objective noise and on the negative health impacts of noise.
\end{abstract}

Keywords: modern environmental problem, noise, recognizing harmful noise impact

\section{Összefoglalás}

A modern környezeti probléma láthatatlan módon szivárgott be az emberek mindennapjaiba, ma már átszövi a napi cselekvési folyamatokat és több szempontból része életünknek. Ezzel együtt számos környezeti hatás alakult ki, mellyel együtt élünk, illetve kisebb vagy nagyobb sikerrel küzdünk ellene. Már aki küzd a környezeti hatások ellen, mivel sokan nem is tudják, hogy mivel kell számolnia a lakókörnyezetben, az utcán, utazás közben vagy a munkahelyen, esetleg a szórakozóhelyeken. A környezeti hatások között kiemelt figyelmet érdemel a zaj, amire a legtöbben azonnal reagálnak, az észlelést tekintve elsődleges helyen szerepel. A mindennapokban fellépő zaj jellemzőiröl, a zajterhelési értékekről és a szubjektív zajjal összefüggő zavarásról, egészségkárosító hatásról ad tájékoztatást jelen beszámoló.

Kulcsszavak: modern környezeti probléma, zaj, káros zajhatás felismerése

\section{Bevezetés}

A környezeti igénybevétel sarokköve az eredeti környezeti állapot megváltozása, ami a létfenntartással, a kialakult társadalmi normáknak megfelelö viselkedésformákkal, valamint a mindennapi tevékenységek miatt fellépő hatásokkal függ össze.

Ezzel együtt általános felfogássá vált, hogy a környezet állapota a fokozódó terhelés miatt folyamatosan és megállíthatatlanul romlik, azonban ez a felfogás nem értelme- zi részleteiben az ok-okozati összefüggéseket. Célravezetőbb az a megközelítés, hogy a környezeti jellemzők átmeneti vagy tartós változásáról beszéljünk, és a környezeti állapottényezők függvényében keressük a megoldást a szennyezés, illetve az anyag és energia kibocsátások csökkentésére. Ennek feltétele, hogy a korábbiaknál nagyobb hangsúlyt kapjon az állapotváltozás megismerése és kezelése, valamint a szennyezési folyamatok megfordításával és a környezeti állapot fokozatos javításával kapcsolatos 
lehetőségek kutatása. Az eddig feltárt lehetőségeknek azonban a rendelkezésre álló technológiák mellett is gátat szab a környezethasználati tevékenységek széles körü elfogadottsága és az a megszokás, hogy a környezet alakítása az ember igényei szerint történjen. Mindezt tetézi a gépek és technikai eszközök olyan mértékủ elterjedése, ami azok hiánya vagy müködésük kimaradása esetén zavarhoz és a megszokott életvitel átmeneti leállásához vezet.

E tekintetben elsődleges helyen szerepeltetjük a megismerés fázisát, mivel tapasztalatunk szerint sok esetben az érintettek még azzal sincsenek tisztában, hogy az őket érintő környezeti hatás milyen jellemzőkkel bír. A vázolt problémát zajterhelés mért értékein keresztül mutatjuk be bízva abban, hogy az olvasó számára sikerrel világítjuk meg a különböző zajhatásokon keresztül a környezeti állapot javítását eredményező azon lehetőségeket, amit az emberi tényezö és a müszaki eszköz közösen határoz meg.

\section{Modern környezeti probléma}

A környezetben zajló jelenségek kapcsolata olyan sajátos rendszert alkot, ami azt eredményezi, hogy a környezeti hatások is csak összetett jelenségek útján írhatók le [1]. Ezek a jelenségek kiterjednek a környezethasználat okaira is, amit úgy határozunk meg, hogy az emberi tevékenységek folytatása alapvetö tényezővé vált.

Ezzel a meghatározással kívánunk rámutatni arra, hogy a technikai fejlödés során olyan eszközöket és lehetőségeket adtak a kutatók, a feltalálók és a mérnökök az emberiség kezébe, melyek alkalmazása és felhasználása a természetes és eredeti környezet megváltoztatásával és a környezetszennyezési folyamatok generálásával járt.

A technikai fejlődés a környezetszenynyezés mennyiségi és minőségi különbségeit is megteremtette, amivel kialakultak a hagyományos és a modern környezetszeny- nyezés közötti különbségek. Mindez természetesen az emberi tevékenységek szükségszerủ folytatásával van összefüggésben, amit ma már úgy fogalmazhatunk meg, hogy kialakult a modern környezeti probléma.

E tekintetben azonban ki kell emelnünk egy fontos tényt. Sokak számára a környezet igénybevétele azonos a környezetszenynyezéssel. A környezet igénybevétele azonban többféle módon valósulhat meg, és elsődlegesen a környezethasználatról kap szerepet. A környezethasználatot a fellépö hatások szerint két föcsoportra osztjuk az alábbiak szerint:

- tehetetlenségi környezethasználat, ami nem rendelkezik a környezet alapállapotának megváltoztatását eredményező kibocsátással;

- befolyásoló környezethasználat, ami az érintett környezet alapállapotát valamilyen irányban és mértékben befolyásolja.

A befolyásoló környezethasználat kétféle módon valósulhat meg. Nemcsak a környezet állapotának romlásáról beszélünk, vannak ugyanis olyan hatások, melyek lokálisan vagy sok esetben kiterjedten a környezeti helyzet javulását eredményezik.

Környezet igénybevétele azoknál a kibocsátásoknál alakul ki, amikor ténylegesen módosul az eredeti állapot, vagy a környezet valamely elemét hasznosítjuk. Ennek azért tulajdonítunk jelentőséget, mert életünk során folyamatosan találkozunk olyan környezettel, ami mások tevékenysége miatt már megváltozott, sok esetben kedvezötlen állapotjellemzőkkel rendelkezik. Ilyenkor könnyebben alakul ki a tehetetlenségi környezethasználat.

A modern környezeti probléma az embert folyamatos helyváltoztatásra készteti. Ez vagy a létfenntartással van összefüggésben, vagy a kedvezőbb környezeti helyzet keresésére és elfoglalására irányul, ami egyfajta védekezés a hatások ellen. 
Időben magvalósuló környezethasználatot szemléltetjük az 1. ábrán.

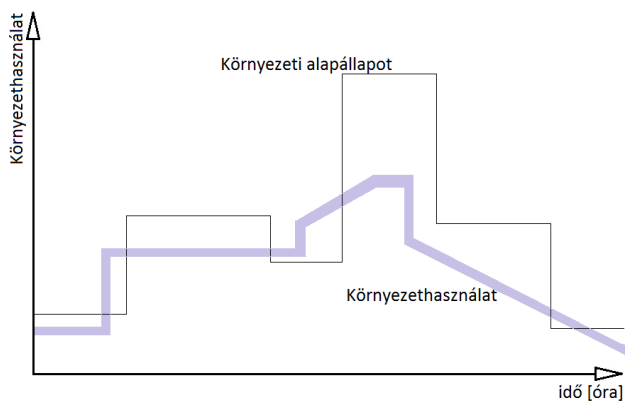

1. ábra. Időben megvalósuló környezethasználat

\section{Környezet és zajhatás}

A környezet állapotát és a környezethasználatból származó terhelési jellemzőket jól szemlélteti a környezeti zaj és a zajhelyzet, ami körülvesz bennünket. A zaj mindenki számára észlelhető hatásként jelenik meg, a környezeti zajterhelés változásaira a szubjektív érzékelés miatt eltérő módon reagálnak az emberek.

Megjegyezzük, hogy amennyiben teljes képet szeretnénk nyerni a zajjal összefüggésben, szakítani kell az antropocentrikus környezetleírással, és a helyzetértékelést a teljes, természeti értékekre is kiterjedő környezetvédelmi rendszerre kell elvégezni. A zaj ennek ellenére elsődlegesen az ember által alakított és használt környezetben okoz problémát, így a továbbiakban ennek bemutatására szorítkozunk.

\subsection{A zajhelyzetről általánosságban}

Általánosan elfogadott álláspont szerint a zajt az ember szempontjából definiáljuk és antropocentrikus értékelési rendszer szerint minősítjük. Ennek a megközelítésnek felel meg az a megfogalmazás, hogy zajnak nevezünk minden olyan nemkívánatos vagy túl hangos hangjelenséget, amely az egyén életfunkcióit, munkáját és pihenésének egyensúlyát zavarja [2]. Ebből a szempontból kiemelt szerepet kap a szubjektivitás.
Az átlagostól eltérő, zavaró hatással járó hanghatás a környezet olyan minőségi jellemzője, ami közvetlen hatást gyakorol az életminőségre. Az érintettek részéről azonnali válaszreakciót vált ki, ami megfigyelhető az állatvilág egyedeinél is, tehát nemcsak az ember sajátossága.

A szubjektív észlelés problémája mellett más szempont is figyelmet érdemel. Ez a környezethasználatok kiindulási fázisa, az ok-okozati összefüggés, aminek az ad jelentőséget, hogy a hangot az ember alakítja át helytelen használattal zajjá. E tekintetben elveszik a hang informatív jelentéstartalma, esetenként a hangélmény szerepe. Ebből a szempontból a környezethasználat és a környezeti zajhelyzet már összefüggéseiben jelenik meg, hiszen az 1. ábra szerint az időben haladva más-más környezeti állapottal találkozunk.

A saját magunk generált környezethasználat során több alkalommal lépünk át egyegy környezeti állapotsíkot és kerülünk tovább egy másik térbe, ami zajosabb vagy csendesebb az előzőnél. Az biztos, hogy a környezeti állapotsíkok átlépése kihat a szubjektív reakciókra. Az emberi megítélés szerint, kedvező kiindulási zajállapotra mutatunk példát a 2 . ábrán.

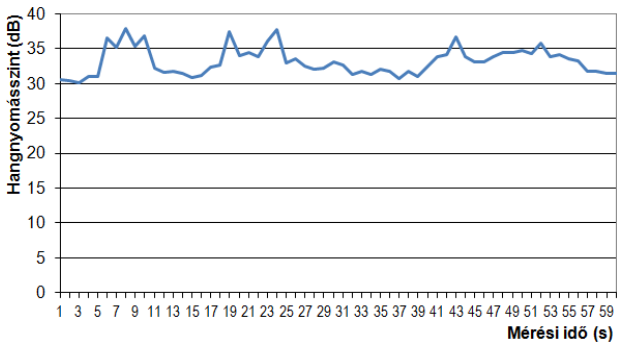

2. ábra. Kedvezö zajállapot hangnyomásszint értékei lakókörnyezetben

A 2. ábrán látható, hogy a hangnyomásszint értékek az időben folyamatosan változnak, instacioner jelleget vesznek fel. Kedvező zajállapotban a változás mértékének szűk határok között kell maradnia. 


\subsection{Környezeti állapotsíkok}

Az időben haladva több környezeti állapotsíkot is átlépünk rövid idő alatt, de létezik olyan életvitel is, ami 3-4, egymástól alig különböző állapotsíkot használ és ezzel huzamosan kedvezö helyzetet tart fenn. Jellemzöen már egy napon belül is találkozhatunk ezzel a jelenséggel attól függően, hogy milyen környezetben élünk. Ezért fontos, hogy az állapotsíkok közötti tér zajjellemzőit megismerjük.

Az általános zajhelyzet megismerése érdekében méréseket végeztünk több olyan környezetben, ami az átlagos napi tevékenységek számára rendelkezésre áll, illetve olyan helyeken, ahol rendszeresen tölt időt egy átlagember. Méréseink célja volt olyan adatok gyüjtése, ami segíti a zajos környezet bemutatását és a káros zajhatások felismerését. Elsőként nagyváros vonatkozásában Budapesten rögzített zajszinteket vizsgáltunk, amit az 1. táblázatban foglaltunk össze.

1. táblázat. Nagyvárosra jellemzö zajszintek

\begin{tabular}{|c|c|c|c|}
\hline Helyszín & $\mathrm{L}_{\max .}$ & $\mathrm{L}_{\min .}$ & $\mathrm{L}_{\text {Aeq }}$ \\
\hline $\mathrm{Z} 1$ & $93,6 \mathrm{~dB}$ & $60,3 \mathrm{~dB}$ & $73,0 \mathrm{~dB}$ \\
\hline $\mathrm{Z} 2$ & $86,8 \mathrm{~dB}$ & $59,7 \mathrm{~dB}$ & $71,1 \mathrm{~dB}$ \\
\hline $\mathrm{Z} 3$ & $80,6 \mathrm{~dB}$ & $52,6 \mathrm{~dB}$ & $67,6 \mathrm{~dB}$ \\
\hline $\mathrm{Z} 4$ & $80,9 \mathrm{~dB}$ & $56,2 \mathrm{~dB}$ & $66,2 \mathrm{~dB}$ \\
\hline
\end{tabular}

Az 1. táblázatban feltüntetett helyszínek azonosítása:

- VI. kerület, Podmaniczky utca 8. szám kollégium épület erkélyén;

- VIII. kerület, József krt. 6. szám intézményépület előtt;

- VII. kerület, Erzsébet krt. 9. szám szállodaépület előtt;

- II. kerület, Pusztaszeri út autóbusz megállóban.

Sokan vannak, akik nem nagyváros központjában vagy sürủn beépített részén töltik az idejüket. A rendelkezésre álló élettér rendkívül változatos, minden emberre jellemző kategorizálás nem is lehetséges.
Ezért további méréseinkhez olyan jellemző helyeket választottunk ki, melyek zajállapota életkorral és viselkedési szokásokkal is összefüggésbe hozható. A környezeti állapotsíkokat ekkor nagyobb időtávlatban húztuk meg és vizsgáltuk, hogy egy-egy életszakaszban milyen zajjal kell számolni a környezetünkben. A vizsgálatból kiragadott hangnyomásszint adatokat szemléltetünk a 3. ábrán.

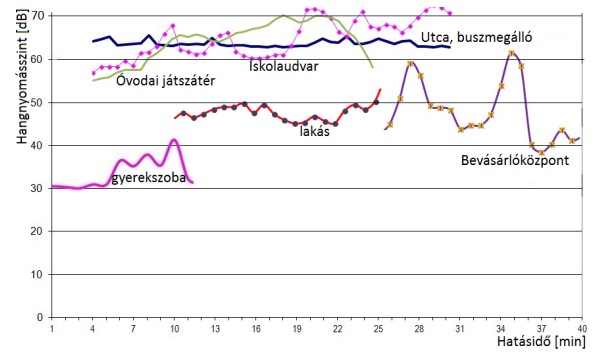

3. ábra. Hangnyomásszint értékek különbözö életterekben

\section{Következtetések}

A bemutatott vizsgálati adatok a modern környezeti probléma témakörében folytatott kutatómunka eredményeként rögzített környezeti jellemzők. Mivel egy vizsgált környezet zajállapota jól tükrözi a környezethasználat mértékét és minőségét, mért hangnyomásszintek alapján jellemezhető a napi cselekvési folyamatok hatása. Ebben a tekintetben kiemeljük a környezeti állapot megismerését, melyhez a tényleges hatás mérésére és értékelésére van szükség. Rövidebb és hosszabb környezeti állapotsíkok felvételével jól látható, hogy a terhelési folyamat változásait szükségszerüen figyelembe kell venni az értékelésnél.

\section{Szakirodalmi hivatkozások}

[1] Bera, J.; Pokorádi, L.: Müszaki folyamatok hatása a környezetbiztonságra, EME kiadó, Kolozsvár, 2014, pp. 57-60.

[2] Moser, M.; Pálmai, Gy.: A környezetvédelem alapjai,Nemzedékek Tudása Tankönyvkiadó, Budapest, 2006, 512 p. 